Jurnal Indonesia Sosial Teknologi: p-ISSN: 2723 - 6609

e-ISSN : 2745-5254

Vol. 2, No. 7 Juli 2021

\title{
KEPASTIAN HUKUM PENYELESAIAN SENGKETA E-COMMERCE DI INDONESIA SECARA ONLINE
}

\author{
Stefani \\ Universitas Jember \\ Email: cmstefani94@gmail.com
}

\begin{abstract}
Abstrak
E-commerce adalah bentuk perdagangan secara elektronik yang memberikan penawaran transaksi yang lebih cepat, mudah dan praktis serta mampu mempertemukan pembeli dengan berbagai macam penjual yang berbeda dalam suatu media. Pengembangan e-commerce juga dituntut dalam keamanan, kenyamanan dalam melakukan transaksi serta kesiapan sumber dayanya sehingga tidak menghambat perkembangan kegiatan perekonomian digital dan meminimalisir resiko. Penelitian ini bertujuan untuk menganalisis penyelesaian sengketa e-commerce secara online di Indonesia serta menemukan kepastian hukumnya. Penulis menggunakan metode penelitian yuridis normatif dengan pendekatan perundang-undangan dan pendeketan konseptual. Terdapat beberapa peraturan peruindang-undangan yang mengatur mengenai penyelesaian sengketa $e$ commerce, seperti Undang-Undang Nomor 8 Tahun 1999 tentang Perlindungan Konsumen yang bertujuan untuk melindungi konsumen, Undang-Undang Informasi dan Transaksi Elektronik Nomor 11 tahun 2008 jo Undang-undang Nomor 19 tahun 2016, serta dalam Undang-Undang Perdagangan Nomor 7 tahun 2014. Penyelesaian sengketa dapat melalui litigasi atau non litigasi. Online Dispute Resolution adalah salah satu bentuk penyelesaian non litigasi. Namun ODR belum diatur secara khusus di Indonesia. Hukum harus dapat memberikan kepastian dan kemanfaatan bagi masyarakat (konsumen). Kesimpulan yang didapat yaitu belum terdapat kepastian hukum terkait sistem online dispute resolution di Indonesia.
\end{abstract}

Kata kunci: e-commerce; kepastian hukum; sengketa; penyelesaian.

\section{Abstract}

E-commerce is a form of electronic commerce. The emergence of e-commerce provides transaction offers that are faster, easier, and more practical as well as being able to bring together buyers with a variety of different sellers in one medium. The development of e-commerce is also required in terms of security, convenience in conducting transactions, and the readiness of its resources so that it does not hinder the development of digital economic activities and minimize risks. This study aims to analyze online e-commerce dispute resolution inIndonesia and find the legal certainty. The author uses a normative juridical research method with a statute approach and a conceptual approach. There are several laws and regulations governing e-commerce dispute resolution, such as Law Number 8 of 1999 concerning Consumer Protection which aims to protect consumers, Law on Information and Electronic Transactions Number 11 of 2008 in conjunction with 
Law Number 19 of 2016, as well as in the Trade Law Number 7 of 2014. Disputes can be settled through litigation or non-litigation. Online Dispute Resolution is a form of non-litigation settlement. However, ODR has not been specifically regulated in Indonesia. The law must be able to provide certainty and benefit to the community (consumers). The conclusion that can be drawn is that there is no legal certainty regarding the online dispute resolution system in Indonesia.

Keywords: e-commerce; legal certainty; dispute; resolution.

\section{Pendahuluan}

Kemajuan teknologi kini semakin pesat dan melekat dengan kehidupan manusia. Perkembangan teknologi informasi dan komunikasi membuat hubungan dunia menjadi tanpa batas, terdapat perubahan secara signifikan dan cepat dalam berbagai bidang kehidupan. Penggunaan teknologi dan internet tidak lagi hanya sebatas untuk mengakses informasi pada sosial media melainkan juga sebagai sarana transaksi jual beli yang dikenal pula dengan istilah e-commerce. E-commerce adalah bentuk perdagangan secara elektronik; yakni pertukaran barang dan/atau jasa serta informasi (Romindo et al., 2019). Hal ini tentunya sangat berdampak bagi perkembangan bidang bisnis di Indonesia. Pemanfaatan internet dalam dunia bisnis dilakukan dengan alasan efisiensi serta modernisasi untuk menjangkau pasar yang lebih luas.

Hadirnya e-commerce memberikan penawaran transaksi yang lebih cepat, mudah dan praktis serta mampu mempertemukan pembeli dengan berbagai macam penjual yang berbeda dalam suatu media (Sitompul, Syaifuddin, \& Yahanan, 2016). Dengan adanya e-commerce pembeli tidak perlu lagi berkunjung ke toko fisik untuk membeli suatu barang melainkan cukup memesan secara online dan membaca persyaratan yang telah dibuat oleh si penjual menggunakan media elektronik. Besarnya jumlah pengguna internet di Indonesia menjadi salah satu faktor pendorong berkembangnya transaksi perdagangan elektronik di Indonesia. Pemerintah melihat potensi dalam bidang ekonomi tersebut sehingga memiliki tujuan untuk mendukung pengembangan perdagangan elektronik di Indonesia. Budi Raharjo mengungkapkan bahwa Indonesia berpotensi dan memiliki kompeten cukup untuk mengembangkan $e$ commerce (Putra, 2014). Pengembangan e-commerce juga dituntut dalam keamanan, kenyamanan dalam melakukan transaksi serta kesiapan sumber dayanya sehingga tidak menghambat perkembangan kegiatan perekonomian digital dan meminimalisir resiko.

Pertumbuhan e-commerce di Indonesia meningkat pesat, berdasarkan data tahun 2017 menurut ilmu One Data, sepuluh peringkat teratas terdapat empat $e$-commerce dan enam marketplace yang mendominasi bisnis digital dipimpin oleh Lazada, Tokopedia, Blibli, Shopee, Bukalapak. Menurut Kementerian Komunikasi dan Informatika, Indonesia sendiri menduduki peringkat ketiga di Asia dalam jumlah pengguna internet. E-commerce sendiri terbagi menjadi beberapa macam seperti iklan baris, online marketplace, shopping mall, toko online, serta toko online di media sosial. Berbagai macam layanan e-commerce membuat persaingan e-commerce di Indonesia semakin kuat dan menunjukkan bahwa ada potensi besar terhadap perekonomian di Indonesia. 
Transaksi melalui perdagangan elektronik tidak selalu memberikan keuntungan saja, tetapi terdapat pula kelemahan dalam bertransaksi di dunia maya.

Transaksi jual beli merupakan salah satu jenis perjanjian yang diatur dalam Kitab Undang-Undang Hukum Perdata buku III, sedangkan perdagangan elektronik merupakan bentuk inovasi dari jual beli tersebut. Kekuatan mengikatnya perjanjian ini berawal dari adanya sepakat antara kedua pihak yang dinyatakan baik secara tertulis maupun lisan yang mengikat para pihak dengan segala akibat hukumnya (Suharnoko, 2004). Seringkali dalam setiap transaksi jual beli baik yang dilakukan secara langsung maupun secara online melalui e-commerce konsumen merupakan pihak yang lemah, dan hak-haknya seringkali tidak terpenuhi. Mengenai hak dan kewajiban baik pelaku usaha maupun konsumen telah diatur dalam Undang-Undang Perlindungan Konsumen Nomor 8 tahun 1999. E-commerce tidak sepenuhnya selalu menguntungkan konsumen sebab lemahnya regulasi yang melindungi konsumen, produsen e-commerce belum sepenuhnya beritikad baik, belum ada perlindungan data konsumen.

Pemerintah mendukung hadirnya e-commerce di Indonesia dengan adanya aturan secara umum dalam Undang-undang, baik dalam Undang-Undang Perlindungan Konsumen maupun Undang-Undang Informasi dan Transaksi Elektronik Nomor 11 tahun 2008 jo Undang-undang Nomor 19 tahun 2016, serta dalam Undang-Undang Perdagangan Nomor 7 tahun 2014. Pada dasarnya jual beli dalam e-commerce memiliki konsep yang sama dengan jual beli secara langsung yaitu dengan adanya tahapan penawaran dan penerimaan. Artinya ada persetujuan dari pihak konsumen, namun hal ini tak lepas juga dapat menimbulkan sengketa yang timbul dari wanprestasi yang dialami oleh pihak konsumen ataupun pihak penjual yang memungkinkan timbulnya gugatan. Para pihak yang bersengketa tentu ingin segera menuntaskan permasalahan mereka secara efektif dan efisien, terlebih lagi apabila pihak yang bersengketa berada pada wilayah yurisdiksi yang berbeda. Sengketa tidak hanya terjadi karena wanprestasi melainkan dapat pula karena perbuatan melanggar hukum. Salah satu unsur penting dari perbuatan melawan hukum yaitu tuntutan ganti kerugian.

Semakin meningkatnya jumlah transaksi jual beli online maka semakin meningkat pula angka sengketa yang terjadi dalam transaksi perdagangan elektronik. Penyelesaian sengketa diselenggarakan untuk mencapai kesepakatan mengenai bentuk dan besarnya ganti rugi dan/atau mengenai tindakan tertentu untuk menjamin tidak terulangnya lagi kerugian yang diderita konsumen. Ketua Pengurus Harian YLKI Tulus Abadi mencatat sepanjang 2017, lembaga tersebut menerima 642 pengaduan, yang 16 persen di antaranya atau 101 pengaduan terkait transaksi belanja online. Karya tulis ini bertujuan untuk menganalisis mengenai prinsip kepastian hukum dalam penyelesaian sengketa transaksi e-commerce di Indonesia secara online. Dalam mencapai tujuan tersebut, penulis menggunakan teori tujuan hukum yaitu kepastian hukum, keadilan hukum dan kemanfaatan hukum.

Sebagai bahan perbandingan untuk penelitian maka penulis mencantumkan penelitian terdahulu yang membahas mengenai topik yang relevan yaitu oleh Rachel Oktalia Cahyono, dalam karyanya yang berjudul Kepastian Hukum Dalam Perjanjian 
Electronic Commerce. Karya tulis tersebut pada intinya memuat mengenai upaya hukum atas sengketa dalam transaksi di e-commerce. pada penelitian tersebut lebih berfokus pada perjanjian yang dibuat oleh para pihak sebelum melakukan transaksi dalam e-commerce. Perjanjian online yang dibuat untuk melindungi para pihak dalam transaksi, sedangkan dalam karya tulis ini lebih berfokus pada kepastian hukum penyelesaian sengketa e-commerce. Penelitian ini penting dilakukan guna memberikan bentuk penyelesaian sengketa yang lebih efisien, cepat, dan mudah digunakan bagi para pihak yang terlibat dalam transaksi e-commerce.

\section{Metode Penelitian}

Dalam penelitian ini penulis menggunakan metode penelitian hukum normatif atau juga dikenal dengan yuridis normatif yaitu penelitian hukum dengan mencari kebenaran koherensi dari aturan-aturan hukum, norma hukum, maupun prinsip hukum (Marzuki, 2019). Penelitian hukum yang dilakukan dengan cara mengidentifikasi masalah, melakukan penalaran, serta menganalisis masalah hukum yang ada sehingga dapat menjawab isu hukum yang diteliti. Pendekatan penelitian yang dapat digunakan peneliti terdapat lima macam yaitu pendekatan kasus, pendekatan konseptual, pendekatan perundang-undangan, pendekatan historis, serta pendekatan komparatif. Berdasarkan kelima pendekatan diatas, maka penulis menggunakan dua macam pendekatan yaitu berupa pendekatan perUndang-undangan serta pendekatan konseptual.

1. Pendekatan Perundang-undangan

Pendekatan dengan undang-undang yaitu penelitian yang dilakukan dengan menilik dari undang-undang ataupun regulasi yang sesuai dengan fokus pada isu hukum yang diteliti. Penggunaan pendekatan ini untuk mengetahui kesesuaian antara undangundang ataupun regulasi dengan peraturan lainnya yang berkaitan dengan isu hukum yang dibahas.

2. Pendekatan Konseptual

Pendekatan konsep ialah pendekatan dengan menggunakan pandangan hukum yang ada, juga doktrin-doktrin ilmu hukum yang dapat digunakan sebagai suatu argumentasi dalam menganalisis isu hukum. Artinya bahwa peneliti menggunakan doktrin, konsep, maupun pandangan yang berkembang dan telah ada untuk membantu dalam memecahkan isu hukum yang dihadapi dan mendapatkan suatu kesimpulan.

\section{Hasil dan Pembahasan}

\section{Peraturan Perundang-Undangan di Indonesia Tentang Penyelesaian Sengketa E-commerce}

E-commerce memiliki karakter sebagai berikut: transaksi oleh dua pihak penjual dan pembeli, terjadinya pertukaran atas barang/jasa/informasi, serta penggunaan sistem elektronik dalam transaksinya (Romindo et al., 2019). Semakin meningkatnya penggunaan e-commerce di Indonesia menyebabkan peningkatan jumlah sengketa yang terjadi saat transaksi elektronik dilakukan. E-commerce sebagai suatu media yang 
mencakup berbagai hal seperti jaringan komunikasi, penyimpanan, pengamanan, pengambilan data serta banyak elemen lainnya. E-commerce merupakan transaksi perdagangan yang dimungkinkan secara digital antar organisasi dengan organisasi atau dengan individual serta antar individual dengan individual (Sarwono \& Prihartono, 2012). Tingkat kerumitan yang cukup tinggi tentunya sangat riskan untuk terjadi malfungsi sehingga berbagai pihak perlu meminimalisir dampak negatif yang mungkin terjadi agar tidak merugikan berbagai pihak. Posisi pembeli (konsumen) merupakan posisi yang paling lemah, cenderung menjadi korban atas tindakan sewenang-wenang pelaku usaha dan memerlukan perlindungan hukum untuk dapat memberikan keamanan, dan penegakan hukum yang tegas (Hamid \& SH, 2017). Kegiatan jual beli yang mengglobal ini sangat riskan karena juga menyangkut transaksi antar negara. Penjual harus menyampaikan informasi kepada konsumen dengan benar, jujur dan jelas serta tidak memberikan pernyataan yang dapat menyesatkan konsumen (MARPI \& Kom, 2020).

Adanya e-commerce tidak memungkiri terhadap kemungkinan adanya sengketa. Sengketa merupakan hal yang dianggap buruk dan patut untuk dihindari/dicegah. Penyelesaian sengketa pada jaman dahulu dilakukan dengan cara informal berdasarkan hukum adat ataupubn kebiasaan, dan kini berkembang dengan berdasarkan hukum tertulis di Indonesia (Rahmawayi, SH, \& Rukiyah Lubis, 2018). Terdapat UndangUndang Nomor 8 Tahun 1999 tentang Perlindungan Konsumen yang bertujuan untuk melindungi konsumen dari sengketa yang dapat saja terjadi. Pemerintah hadir dengan memberikan peraturan-peraturan umum mengenai perdagangan elektronik yang tercantum di dalam Undang-Undang Nomor 11 tahun 2008 jo Undang-Undang Nomor 19 tahun 2016 tentang ITE, tercantum dalam pasal 10 ayat (1) bahwa setiap pelaku usaha yang menyelenggarakan Transaksi Elektronik dapat disertifikasi oleh Lembaga Sertifikasi Keandalan. Sertifikasi keandalan sebagai bentuk bukti bahwa pelaku usaha telah melalui penilaian dan audit dari badan berwenang sehinggga memiliki logo sertifikasi dalam bentuk trust mark pada laman (home page) pelaku usaha. Sertifikasi keandalan merupakan bentuk jaminan hukum dari negara kepada masyarakat agar aman dalam bertransaksi melalui e-commerce, namun faktanya masih banyak kasus penipuan yang terjadi dalam e-commerce sebab belum diterapkannya lembaga sertifikasi keandalan di Indonesia secara masif. Peraturan mengenai Sertifikat Keandalan juga tercantum dalam pasal 42 ayat (3) Peraturan Pemerintah Nomor 71 Tahun 2019 Tentang Penyelenggaraan Sistem dan Transaksi Elektronik. Pada tahun 2013 pemerintah berupaya mendorong pertumbuhan Lembaga Sertifikasi Keandalan (selanjutnya disebut LSK), yang tentunya menjadi lapangan usaha baru bagi industri IT.

Salah satu LSK yang ada yakni $i$-trust Telkom namun hanya untuk penggunaan internal dan belum ada yang untuk komersil. LSK sebagai lembaga penjamin bagi konsumen untuk mempercayai suatu e-commerce masih belum dapat terpenuhi sehingga masih menyebabkan terjadi banyak kasus sengketa pada e-commerce. Banyak kendala yang dialami pemerintah untuk dapat menyelaraskan antara pertumbuhan e-commerce di Indonesia dengan peraturan hukum yang mengatur. Manfaat hadirnya LSK tentu 
dapat mencegah terjadinya sengketa sebab adanya jaminan dari negara yang melindungi konsumen sebagai pihak yang lemah dalam transaksi. Masalah legal di internet yang belum terjangkau oleh hukum secara jelas seperti mengenai kontrak online dan $e$ commerce. Dalam hal kontrak dilakukan di cyberspace, peraturan tidak memiliki perbedaan. Namun, bagaimanapun terdapat keadaan di dunia maya yang sama sekali baru dan tidak ada suatu ketentuan pun yang berlaku sehingga menyebabkan ketidakpastian dan resiko bisnis sangat tinggi. Perubahan drastis dari perilaku komunikasi yang biasanya menggunakan kertas (paper) dan kemudian menggunakan elektronik mengubah sistem kehidupan masyarakat. Gaya hidup yang beralih dari wujud (fisik) ke elektronik (non fisik) disebutkan sebagai ruang maya (cyberspace). Dalam hukum perdata bisnis, kegiatan didunia maya ini terjadi dalam bentuk kontrak dagang elektronik (E-commerce). Kontrak dagang tidak lagi merupakan paper-based economy, tetapi digital electronic economy.

Perlu diakui bahwa UU ITE masih memerlukan peraturan turunan sebagai petunjuk pelaksanaan mengenai implementasi transaksi elektronik itu sendiri. Pengaturan transaksi E-commerce dalam UU ITE dapat dijabarkan sebagai berikut.:

1) Diperlukannya keberadaan suatu Lembaga Sertifikasi Keandalan untuk melakukan sertifikasi terhadap pihak yang akan melakukan transaksi;

2) Pengaturan pelaksanaan Transaksi Elektronik (Pasal 17 Ayat (3);

3) Pengaturan mengenai Kontrak Elektronik terhadap Transaksi Elektronik (Pasal 18 Ayat (1));

4) Penyelesaian Sengketa atas Transaksi Elektronik (Pasal 18 Ayat (3);

5) Sistem Elektronik sebagai sistem pelaksanaan Transaksi Elektronik (Pasal 19);

6) Pengaturan mengenai Agen Elektronik sebagai perantara dalam melakukan Transaksi Elektronik (Pasal 21 dan 22) (Hanim, 2014).

Peraturan pelaksana diperlukan untuk menjamin adanya kepastian dalam hukum yang dapat melindungi konsumen maupun para pihak lainnya.

Perdagangan melalui sistem elektronik juga diatur dalam Undang-undang Perdagangan Nomor 7 Tahun 2014 pasal 1 angka 24, yaitu merupakan perdagangan yang transaksinya dilakukan melalui serangkaian perangkat dan prosedur elektronik. Dalam Undang-Undang Perdagangan pasal 65 mengenai perdagangan melalui sistem elektronik, pada pasal 65 ayat (5) bahwa: dalam hal terjadi sengketa dengan transaksi dagang melalui sistem elektronik, orang atau badan usaha yang mengalami sengketa dapat menyelesaikan sengketa tersebut melalui pengadilan atau melalui mekanisme penyelesaian sengketa lainnya. Hukum memberikan pilihan penyelesaian sengketa melalui litigasi ataupun non litigasi. Kedua pilihan tersebut tentunya memiliki kekurangan dan kelebihannya. Penyelesaian melalui litigasi yang umunya lebih didominasi pihak yang kuat tentu sangat jarang menghasilkan putusan win-win solution. Selain itu penyelesaian melalui pengadilan memakan waktu yang lama, dan biasanya digunakan sebagai langkah terakhir apabila langkah non litigasi tidak dapat menyelesaiakan masalah. Penyelesaian sengketa litigasi yaitu melalui jalur pengadilan kini mulai ditinggalkan karena memakan waktu yang lama, mahal serta prosedur yang 
berbelit (Hariyani, Serfiyani, \& Purnomo, 2018). Alternatif Penyelesaian Sengketa merupakan langkah lain yang dapat ditempuh pihak bersengketa yang telah diatur dalam Undang-Undang Nomor 30 tahun 1999 Tentang Arbitrase dan Alternatif Penyelesaian Sengketa.

\section{Kepastian Hukum Penyelesaian Sengketa E-commerce Melalui Online Dispute Resolution di Indonesia}

Menurut Utrecht, kepastian hukum mengandung dua pengertian, yaitu pertama, adanya aturan yang bersifat umum membuat individu mengetahui perbuatan apa yang boleh atau tidak boleh dilakukan, dan kedua, berupa keamanan hukum bagi individu dari kesewenangan pemerintah karena dengan adanya aturan yang bersifat umum itu individu dapat mengetahui apa saja yang boleh dibebankan atau dilakukan oleh negara terhadap individu (Syahrani \& Hukum, 1999). Teori kepastian hukum adalah suatu yang telah pasti serta tidak menimbulkan multitafsir; kontradiktif dan masyarakat dapat melaksanakan (Sulfinadia, 2020). Kepastian hukum menghendaki adanya upaya pengaturan hukum dalam perundang-undangan yang dibuat oleh pihak yang berwenang dan berwibawa, sehingga aturan-aturan itu memiliki aspek yuridis yang dapat menjamin adanya kepastian bahwa hukum berfungsi sebagai suatu peraturan yang harus ditaati (Asikin, 2012).

Kepastian dan keadilan bukanlah sekedar tuntutan moral, melainkan secara factual mencirikan hukum. Suatu hukum yang tidak pasti dan tidak mau adil bukan sekedar hukum yang buruk. Kepastian dalam hukum merupakan suatu bentuk jaminan akan adanya keadilan yang didapatkan masyarakat dihadapan hukum. Kepastian hukum didapatkan dari aturan-aturan hukum yang berlaku, peraturan-peraturan tersebut sebagi batas antara hak dan kewajiban, perintah dan larangan. Penyelesaian sengketa melalui litigasi dan non-litigasi. Penyelesaian sengketa melalui litigasi yakni sebagian besar tugasnya adalah menyelesaikan sengketa dengan menjatuhkan putusan (constitutive) misalnya menjatuhkan putusan atas sengketa waris, perbuatan melawan hukum dan sebagian kecil tugasnya adalah penangkalan sengketa dengan menjatuhkan penetapan pengadilan (deklaratoir) misalnya penetapan wali, penetapan anak angkat dan lain-lain (Wiryawan, Artadi, \& Atmaja, 2010). Nonlitigasi sebagai kebalikan dari litigasi (argumentum analogium) adalah untuk menyelesaikan sengketa di luar pengadilan melalui perdamaian dan penangkalan sengketa dengan perancangan-perancangan kontrak yang baik. Penyelesaian sengketa secara nonlitigasi meliputi bidang yang sangat luas bahkan mencakup seluruh aspek kehidupan yang dapat diselesaikan secara hukum. Online Dipute Resolution (untuk selanjutnya disebut ODR) merupakan salah satu bentuk Alternatif Penyelesaian Sengketa, yang juga dikenal dengan model arbitrase online. Pengaturan mengenai ODR secara jelas dan rinci belum terdapat dalam peraturan hukum di Indonesia.

ODR memiliki kelebihan dimana dalam penggunaannya yang efisien dan efektif, sert tidak membutuhkan biaya yang besar. Tata cara ODR tidak jauh berbeda dengan APS, perbedaan yang mendasar hanya pada kehadiran fisik para pihak yang terlibat 
tidak diperlukan lagi. Pada umumnya meskipun belum ada peraturan yang lebih jelas mengenai ODR di Indonesia, pada prakteknya para pihak yang bersengketa lebih memilih menggunakan ODR karena ketidak berpihakannya dan lebih mematuhi standar. Penyelesaian sengketa dengan menggunakan ODR dimungkinkan untuk dilakukan karena tanda tangan elektronik kini dapat menjadi bukti hukum sesuai dengan UU ITE (Hariyani et al., 2018). Sistem penyelesaian sengketa melalui ODR tentu akan menjadi cara yang akan berkembang di masa mendatang mengingat semakin meningkatnya pengguna e-commerce di Indonesia, dan banyaknya sengketa yang dialami konsumen. Pada bulan Maret 1998 dalam "communication on the out of court settlement of court consumer disputes", komisi Eropa telah mempresentasikan standar minimun dari proses ODR, antara lain:

1. Pembuat keputusan harus bersifat independen dari segala asosiasi profesional yang menunjuk dirinya (independen).

2. Proses dalam penyelesaian sengketa harus bersifat transparan (prinsip transparan).

3. Para pihak harus diberikan kesempatan yang sama untuk mengemukakan pendapatnya, serta diberikan akses yang sama untuk membuktikan (prinsip adversarial).

4. Konsumen harus mampu untuk mewakili dirinya sendiri dalam proses penyelesaian sengketa dan bebas dari biaya apapun. Putusan harus dibuat secara cepat dan pembuat putusan harus mempunyai peran aktif dalam proses penyelesaian sengketa (prinsip efektifitas).

5. Konsumen tidak boleh dikesampingkan dari ketentuan/aturan wajib dari hukum tempat badan pembuat keputusan berada dan dari negara dimana konsumen tercacat sebagai warga negara (prinsip legalitas).

6. Jika putusan mengikat kepada konsumen tanpa bantuan pengadilan, maka konsumen harus menerimanya dan bersikap waspada (prinsip kebebasan).

7. Pada semua tahap penyelesaian sengketa, konsumen dapat diwakili oleh atau dibantu oleh pihak ketiga, misalnya pengacara (prinsip perwakilian) (Basarah, 2011).

Dalam Undang-undang Nomor 30 tahun 1999 tentang Arbitrase dan APS belum tercantum secara jelas. Pada pasal 1 ayat (3) UU No. 30 Tahun 1999 menyatakan bahwa perjanjian arbitrase adalah suatu kesepakatan berupa klausula arbitrase yang tercantum dalam suatu perjanjian tertulis yang dibuat para pihak sebelum timbul sengketa, atau suatu perjanjian arbitrase tersendiri yang dibuat para pihak setelah timbul sengketa. Mengenai ODR tersirat dalam pasal 4 ayat (3) UU Nomor 30 Tahun 1999 yaitu dalam hal disepakati penyelesaian sengketa melalui arbitrase terjadi dalam bentuk pertukaran surat, maka pengiriman teleks, telegram, faksimili, e-mail atau dalam bentuk sarana komunikasi lainnya, wajib disertai dengan suatu catatan penerimaan oleh para pihak. Isi pasal tersebut dapat menjadi acuan bagi para pihak untuk melaksanakan ODR. Namun belum ada kepastian payung hukum yang jelas mengatur mengenai ODR, seperti bagaimana pendaftaran ODR nantinya, apakah juga didaftarkan ke pengadilan seperti 
arbitrase pada umumnya dimana arbitrase nasional di pengadilan negeri sedangkan untuk arbitrase internasional didaftarkan pada pengadilan negeri Jakarta Pusat. UU ITE berperan penting di masa digitalisasi ini untuk memenuhi segala unsur hukum yang dibutuhkan masyarakat dalam berselancar di dunia maya. Perlu adanya kepastian hukum terlebih lagi yang mengatur mengenai ODR secara jelas untuk mempermudah masyarakt dalam menerapkan sistem ODR.

\section{Kemanfaatan Hukum Terhadap Penyelesaian Sengketa Melalui Online Dispute Resolution}

Peraturan e-commerce ditujukan untuk memberikan kepastian dan kesepahaman mengenai apa yang dimaksud dengan e-commerce serta menjamin perlindungan, kepastian kepada pelaku usaha elektronik, penyelenggara e-commerce, dan konsumen dalam melakukan kegiatan perdagangan melalui sistem elektronik. Dalam peraturan tersebut tentunya mengandung asas kemanfaatan. Asas kemanfaatan merupakan asas yang menyertai kepastian hukum dan keadilan hukum (Hidayat, 2018). Artinya bahwa selain kepastian dan keadilan dihadapan hukum, hukum harus memiliki manfaat bagi masyarakat. Hukum hadir bukan hanya sebagai pintu pembatas untuk mebatasi hak dan kewajiban, tetapi juga bermanfaat bagi masyarakat untuk memenuhi kebutuhan perlindungan masyarakat oleh negara. Hukum bertujuan sebesar-besarnya hanya untuk kemanfaatan manusia yang dimaksud dengan memberikan kebahagiaan bagi umat manusia (Gede \& Putu, 2018). ODR yang merupakan salah satu alternatif penyelesaian sengketa tentunya akan memiliki manfaat yang besar bagi masyarakat apabila nantinya dapat digunakan secara massal oleh masyarakat. Saat ini masyarakat sering kali melakukan transaksi dalam e-commerce seperti dalam tokopedia, shopee, dan sebagainya. Sering kali konsumen dihadapai sengketa dengan pihak penjual karena berbagai alasan, dan penyedia layanan belum mampu untuk membantu menyelesaikan permasalahan. Dengan adanya lembaga ODR yang dapat beroperasi untuk umum tentunya akan memudahkan konsumen untuk menyelesaikan permasalah secara online.

Para pihak tidak perlu untuk hadir secara fisik dalam bernegosiasi dan sebagainya, sebab dapat dilakukan secara online. Selain itu para pihak tidak perlu lagi takut akan menghabiskan biaya mahal seperti saat di pengadilan, dan jangka waktu penyelesaian sengketa yang lebih cepat sehingga putusan final didapat secepat mungkin. Segala kemanfaatan tersebut tentunya sangat menguntungkan bagi para pihak yang bersengketa. ODR dalam penggunaan melalui sistem online dengan menggunakan email, nomor telepon. Tidak menutup kemungkinan bahwa dimasa mendatang para pebisnis tentu lebih memilih penyelesaian melalui online dispute resolution, namun belum ada lembaga penyedia jasa layanan ODR yang beroperasi di Indonesia. Hal ini tentunya dapat menjadi peluang bagi para investor di Indonesia untuk mulai mengembangkan lembaga penyedia jasa layanan ODR di Indonesia yang memiliki prospek besar dimasa mendatang, sehingga memberi kemanfaatan dan peluang bagi investor Indonesia. ODR sendiri telah digunakan salah satunya di Amerika, dan tergolong baru di Indonesia. ODR merupakan suatu wadah bagi masyarakat yang 
seharusnya dapat digunakan secara efektif, namun diperlukan peraturan hukum yang jelas. Proses penyelesaian sengketa secara online terdiri dari:

a) Para pihak setuju dalam bentuk perjanjian untuk menyelesaikan sengketa melalui arbitrase online.;

b) Pemberitahuan kepada para pihak dan perhitungan jangka waktu penyelesaian sengketa oleh Provider.;

c) Pemohon harus membuat dokumen yang berisi tuntutan kepada administrative site;

d) Pemberitahuan isi tuntutan Pemohon kepada Termohon oleh Provider;

e) Jawaban atas tuntutan Pemohon oleh Termohon.;

f) Jawaban atas tuntutan balasan.

g) Perpanjangan jangka waktu penyelesaian sengketa;

h) Menggunakan bahasa yang digunakan dalam perjanjian arbitrase,

i) Melakukan hearing;

j) Tempat dari putusan dapat ditentukan oleh para pihak, apabila para pihak tidak menentukan, maka tempat dari putusan ditentukan oleh arbiter

k) Memberitahukan isi putusan.

Langkah-kangkah tersebut merupakan langkah yang harus ditempuh dalam penyelesaian sengketa melalui ODR. Tata cara preoses ODR tersebut disesuaikan dengan kebutuhan hukum yang dapat dipakai pada tempat arbitrase dilaksanakan/diperjanjikan dengan tidak bertentangan dengan kepentiangn umum dan ketertiban. Pemerintah perlu menyiapkan mengenai lembaga penyedia jasa layanan ODR, kesediaan layanan internet yang memadai di Indonesia, peraturan pelaksana mengenai ODR, serta edukasi kepada masyarakat mengenai ODR sehingga masyarakat tidak lagi bingung dan buta arah mengenai tindakan yang harus ditempuh bila ada sengketa dalam transaksi elektronik. Pada Undang-Undang ITE Pasal 41 disebutkan bahwa pemerintah melindungi kepentingan umum dari segala jenis gangguan sebagai akibat penyalahgunaan informasi elektronik dan transaksi elektronik yang mengganggu ketertiban umum, sesuai dengan ketentuan peraturan perundang-undangan. Sistem penyelesaian sengketa melalui ODR ini telah diterapkan di negara lain seperti Amerika, Eropa, dan mampu meningkatkan jumlah pengguna e-commerce dinegara tersebut (Sugiarto, 2019). Indonesia dengan jumlah penduduk lebih dari 200 juta orang tentunya memiliki peluang besar untuk mengembangkan pola transaksi jual beli dalam era digitalisasi ini, sehingga diperlukan peran besar negara untuk mendukung dan mendorong masyarakat dalam membangun perekonomian negara dengan perlindunga hukum yang mampu menjamin kenyamanan dan keamanan masyarakat.

\section{Kesimpulan}

Indonesia memiliki peraturan tentang perdagangan elektronik secara umum dalam Undang-Undang Nomor 11 Tahun 2018 jo Undang-undang Nomor 19 tahun 2016 tentang Informasi dan Transaksi Elektronik, Undang-Undang Nomor 7 tahun 2014 tentang Perdagangan dan Undang-Undang Nomor 30 tahun 1999 tentang Arbitrase dan 
Alternatif Penyelesaian Sengketa. Belum ada kepastian hukum terkait sistem online dispute resolution di Indonesia sebab belum ada peraturan maupun peraturan pelaksana yang menjelaskan secara detail tentang ODR namun peraturan secara umum telah dimuat dalam Undang-Undang ITE dan Undang-Undang Perdagangan, juga UndangUndang Arbitrase dan Alternatif Penyelesaian Sengketa sebagai pedoman ODR. ODR akan sangat bermanfaat bagi masyarakat di masa mendatang melihat dari perkembangan angka pengguna e-commerce di Indonesia, sehingga diperlukan payung hukum yang mampu melindungi masyarakat secara normatif agar Indonesia dapat bersaing dengan negara lain di dunia. 


\section{Bibliografi}

Asikin, Zainal. (2012). Pengantar Tata Hukum Indonesia. Rajagrafindo Persada, Jakarta.

Basarah, Moch. (2011). Prosedur Alternatif Penyelesaian Sengketa Arbitrase Tradisional dan Modern. Yogyakarta: Genta Publishing.

Gede, Atmadja I. Dewa, \& Putu, Budiartha I. Nyoman. (2018). Teori-teori Hukum. Cetakan Pertama, Setara Press Kelompok Intrans Publishing, Malang, Jawa Timur.

Hamid, Abd Haris, \& SH, M. H. (2017). Hukum Perlindungan Konsumen Indonesia (Vol. 1). SAH MEDIA.

Hanim, Lathifah. (2014). PERLINDUNGAN HUKUM BAGI PARA PIHAK DALAM E-COMMERCE SEBAGAI AKIBAT DARI GLOBALISASI EKONOMI. Jurnal Pembaharuan Hukum, 1(2), 191-199.

Hariyani, Iswi, Serfiyani, Cita Yustisia, \& Purnomo, R. Serfianto Dibyo. (2018). Penyelesaian sengketa bisnis: litigasi, negosiasi, konsultasi, pendapat mengikat, mediasi, konsiliasi, adjudikasi, arbitrase, dan penyelesaian sengketa daring. PT Gramedia Pustaka Utama.

Hidayat, Firman. (2018). Tinjauan Asas Kepastian Hukum, Keadilan, Dan Kemanfaatan Dalam Akta Perjanjian Kawin Yang Di Buat Oleh Notaris. Fakultas Hukum UNISSULA.

MARPI, YAPITER, \& Kom, S. (2020). Perlindungan hukum terhadap konsumen atas keabsahan kontrak elektronik dalam transaksi e-commerce. PT. ZONA MEDIA MANDIRI.

Marzuki, Menurut Peter Mahmud. (2019). Ian McLeod, Terry Hutchinson serta Jan Gijssels dan Mark. Hukum Perjanjian, 37.

Putra, Setia. (2014). Perlindungan Hukum Terhadap Konsumen Dalam Transaksi JualBeli Melalui E-Commerce. Jurnal Ilmu Hukum, 5(2), 197-208.

Rahmawayi, Intan Nur, SH, M. H., \& Rukiyah Lubis, S. H. (2018). Win-Win Solution Sengketa Konsumen. Media Pressindo.

Romindo, Romindo, Muttaqin, Muttaqin, Saputra, Didin Hadi, Purba, Deddy Wahyudin, Iswahyudi, M., Banjarnahor, Astri Rumondang, Kusuma, Aditya Halim Perdana, Effendy, Faried, Sulaiman, Oris Krianto, \& Simarmata, Janner. (2019). ECommerce: Implementasi, Strategi dan Inovasinya. Yayasan Kita Menulis.

Sarwono, Jonathan, \& Prihartono, K. (2012). Perdagangan online: cara bisnis di internet. Jakarta: PT Elex Media Komputindo. 
Sitompul, Meline Gerarita, Syaifuddin, M., \& Yahanan, Annalisa. (2016). Online Dispute Resolution (ODR): Prospek Penyelesaian Sengketa E-Commerce di Indonesia. Jurnal Renaissance, 1(2), 75-93.

Sugiarto, Suprihantosa. (2019). ONLINE DISPUTE RESOLUTION (ODR) SEBAGAI ALTERNATIF PENYELESAIAN SENGKETA DI ERA MODERNISASI. Qawãnïn: Journal of Economic Syaria Law, 3(1), 50-65.

Suharnoko, Hukum Perjanjian. (2004). Teori dan Analisa Kasus. Jakarta, Kencana Prenada Media.

Sulfinadia, Hamda. (2020). Meningkatkan Kesadaran Hukum Masyarakat Studi Atas Pelanggaran Peraturan Perundang-Undangan Tentang Perkawinan. Deepublish.

Syahrani, Riduan, \& Hukum, Rangkuman Intisari Ilmu. (1999). Penerbit Citra Aditya Bakti. Bandung.

Wiryawan, I. Wayan, Artadi, I. Ketut, \& Atmaja, Made Jiwa. (2010). Penyelesaian sengketa di luar pengadilan. Udayana University Press. 